\title{
IS THE POOR ESTABLISHMENT AND PERFORMANCE OF HEATHER BEETLE IN TONGARIRO NATIONAL PARK DUE TO THE IMPACT OF PARASITOIDS, PREDATORS OR DISEASE?
}

\author{
P PETERSON $^{1}$, S.V. FOWLER ${ }^{2}$, and P. BARRETT ${ }^{3}$ \\ ${ }^{1}$ Landcare Research, Palmerston North, New Zealand \\ ${ }^{2}$ Landcare Research, Lincoln, New Zealand \\ ${ }^{3}$ Massey University, Palmerston North, New Zealand \\ Corresponding author: petersonp@landcareresearch.co.nz
}

\begin{abstract}
Heather beetle (Lochmaea suturalis), introduced in 1996 into Tongariro National Park, New Zealand to control heather (Calluna vulgaris), has established poorly and only damaged heather at one site. This work investigated whether natural enemies could be reducing heather beetle establishment and impact. No egg, larval or adult parasitism was found. Possible egg predation by a carabid beetle larvae, and occasional attacks on larvae by the native pentatomid (Cermatulus nasalis), were observed in the field. Neither the microsporidian pathogen discovered in some beetles imported from the United Kingdom, nor any other pathogenic diseases, were detected in field-collected beetles in New Zealand. It is suggested that adverse weather was responsible for a collapse in heather beetle numbers at Te Piripiri during 2002. Further efforts to redistribute heather beetle and continued monitoring of beetle numbers, impact, natural enemies and climate at release sites are recommended.
\end{abstract}

Keywords: weed biocontrol, natural enemies, climate.

\section{INTRODUCTION}

Heather (Calluna vulgaris) was deliberately introduced into Tongariro National Park in 1912. It now infests 50,000 ha of the North Island's Central Plateau, including onethird of Tongariro National Park, and biological control is the only feasible management option. In 1996, after 5 years of host-range testing and an environmental impact assessment, the heather beetle (Lochmaea suturalis), sourced from the United Kingdom, was released (Syrett 1990; Smith et al. 1998; Syrett et al. 2000). However by 2001 there was only one site, Te Piripiri, where heather beetle had been established for more than 1 year, despite 17 releases totalling 5700 adults made from 1996 to 1999 (Smith et al. 1998; Fowler et al. 2000). At Te Piripiri though, the main $300 \mathrm{~m}^{2}$ heather patch was impressively damaged, with some heather mortality. Beetles from this site were then used to start a laboratory colony at Palmerston North, and for further releases around Tongariro National Park and more recently at Rotorua. The success of releases of beetles collected from Te Piripiri also appears to have been low in the Tongariro area. In contrast, two of three releases from Te Piripiri, carried out at Rotorua in 2001, had established by 2002, and were already causing visible damage to heather. Over the same period, the numbers of beetles at Te Piripiri, which had been increasing approximately exponentially from their discovery in 1999, suddenly dropped approximately 10 fold.

Heather beetles outbreak sporadically in their native range in Europe, sometimes severely damaging heather. The start of outbreaks is anecdotally linked to various weather patterns and, in one case, to unusually low larval parasitism (Waloff 1987). Food limitation does not appear to be the primary cause of the often-sudden population collapses, as abundant heather is usually still available nearby (S.V. Fowler, unpubl. data). In Europe, field studies show levels of parasitism of $6-100 \%$ of heather beetle larvae by the eulophid wasp, Asecodes mento (Golightly 1962; Waloff 1987) and 0-89\% of adult beetles by the 
tachinid fly, Degeeria collaris (Cameron et al. 1944; Waloff 1987; S.V. Fowler, unpubl. data). No egg parasitism has been detected. Predators, including reduviids, pentatomids, carabids and coccinellids, can attack heather beetle, but were not considered important because of their low numbers and/or slow numerical responses (Cameron et al. 1944).

Heather beetle was released in New Zealand free from European parasitoids and predators, as a result of the careful rearing through one or more generations in quarantine before release. However, released biological control agents can recruit parasitoid and predator species from the fauna in the country into which they are introduced (Cornell \& Hawkins 1993).

Routine checks of heather beetle shipped from the United Kingdom into quarantine in New Zealand detected a microsporidian disease. The beetles in quarantine were then 'line-reared'; offspring from individual females were kept separate in hygienic conditions, and the entire line destroyed if any of the sample insects tested positive for the microsporidian. In this way, the microsporidian was eliminated from existing and newly imported heather beetles in quarantine before the first releases into the field in 1996. Unfortunately, ongoing routine checks of the heather beetles in quarantine in 1999 showed that the disease was present, casting doubt on whether the earlier elimination had been complete. After this, all heather beetles in quarantine were destroyed, and no further importations have been made.

In this paper predation, parasitism and disease as possible contributors to the poor establishment and spread of heather beetle in Tongariro National Park were investigated.

\section{METHODS}

Eighty heather beetle eggs, laid directly onto moss by field-collected adults, were transferred into eight Petri dish bases (ten eggs per dish) and exposed to potential parasitoids and predators under heather plants for 5 days at Te Piripiri during December 2001. Eggs that were recovered after 5 days were transferred into Petri dishes on damp filter paper and the proportion that successfully hatched was recorded. A total of 40 larvae (18 2nd and 22 3rd instars) and two lots of 30 adults were collected from the same site during February 2002, September 2001 and December 2001 respectively. Larvae were reared through to adults, and adults were maintained for a minimum of 40 days, during which time they were checked daily for parasitoid emergence. Larvae and adults were kept individually in Petri dishes with damp filter paper and freshly cut heather. Filter papers and heather shoots were replaced every 2-3 days. Larval rearing and adult maintenance was done at room temperature with natural lighting. Mean minimum and maximum temperatures and humidities were $18-22^{\circ} \mathrm{C}$ and $64-84 \% \mathrm{RH}$ for larvae, $17-26^{\circ} \mathrm{C}$ and $70-94 \% \mathrm{RH}$ for September 2001 adults and $20-25^{\circ} \mathrm{C}$ and $69-94 \%$ RH for December 2001 adults. Dead larvae and adults were inspected for internal parasitoids by microscopic dissection.

Potential predators were sampled in the field by pitfall trapping, sweep netting and visual searching at Te Piripiri, and by sweep netting and visual searching at other release sites within Tongariro National Park between December 2000 and January 2003. Potential predatory species (Table 2) were placed individually onto cut heather shoots inside 430 $\mathrm{cm}^{3}$ vented plastic tubes (stems sealed externally in water filled vials), with seven heather beetle larvae (one $1^{\text {st }}$, two $2^{\text {nd }}$ and four $3^{\text {rd }}$ instar larvae), for 2 weeks in a controlled environment room $\left(22^{\circ} \mathrm{C}, 75 \% \mathrm{RH}, 16: 8 \mathrm{~h}\right.$ light:dark $)$. Four of the 24 tubes were set up without predators as controls for non-predatory related larval death. Dead larvae were removed and inspected under a microscope on 5 occasions and original prey densities restored on two occasions. Cause of death was determined by comparing heather beetle corpses from witnessed predation with those from the control treatment.

To make pathogens easier to detect, heather beetles were reared in crowded, unhygienic and damp conditions. First, several ovipositing adults were field collected and placed in a vented plastic container measuring $100 \times 210 \times 20 \mathrm{~mm}$. Freshly cut heather and water (sprayed) were added to the cage as required but otherwise no maintenance to reduce disease was attempted. After 49 days, 30 of the 158 adults reared through, were removed, smeared onto slides, and microscopically examined for microsporidia using the Giemsa staining procedure (Kalmakoff \& Longworth 1980). 


\section{RESULTS}

Heather beetle eggs concealed in moss under heather for 5 days attracted no parasitism, and no parasites were reared from field collected larvae or adults of heather beetle. However, seven of the 81 (9\%) eggs disappeared, and in one case a carabid larva was found near the lost eggs, most of which were from one dish (Table 1).

TABLE 1: The number of eggs exposed to natural enemies (and subsequently recovered) and the number of larvae and adult heather beetles collected at Te Piripiri.

\begin{tabular}{lccc}
\hline & $\begin{array}{c}\text { No. eggs exposed } \\
\text { (recovered) or } \\
\text { larvae/adults } \\
\text { collected in field }\end{array}$ & $\begin{array}{c}\text { No. eggs hatched or } \\
\text { larvae/adults surviving } \\
\text { from those collected } \\
\text { or recovered } \\
\text { from the field }\end{array}$ & No. parasitised \\
\hline Sept 01 adults & 30 & 25 & 0 \\
Egg & $81(74)$ & 56 & 0 \\
Dec 01 adults & 30 & 19 & 0 \\
$2^{\text {nd }}$ instar & 18 & 11 & 0 \\
$3^{\text {rd } \text { instar }}$ & 22 & 19 & 0 \\
\hline
\end{tabular}

${ }^{1}$ Eggs were considered free of parasitism if they either died without a parasitoid emerging or if larvae successfully hatched. Hatched larvae were not reared. Larvae were considered free of parasitism if they either died without a parasitoid emerging or an internal parasitoid (checked by microscopic dissection) or survived through to the adult stage. Adults were considered free of parasitism if they either died without a parasitoid emerging or an internal parasitoid (checked by microscopic dissection) or survived, feeding and females ovipositing for at least 40 days in the laboratory following field collection.

The native pentatomid (Cermatulus nasalis) was the only predator seen attacking heather beetle larvae in Tongariro National Park. Sweep net samples from Te Piripiri and other release sites within Tongariro National Park revealed crab spiders (Diaea sp.) (Araneae: Thomisidae) and nurseryweb spiders (Dolomedes minor) (Araneae: Pisauridae) were the most common potential predators of heather beetle. No other predatory taxa were common in either sweep netting or pitfall trapping at Te Piripiri, either before or after the heather beetle population collapse.

Diaea sp. and Dolomedes minor rarely fed on heather beetle larvae in laboratory experiments (Table 2). Some other predators collected occasionally were included in laboratory trials because of potentially high consumption rates. Nabis (Australonabis) biformis (Bergroth) (Hemiptera: Nabidae), Cermatulus nasalis (Hemiptera: Pentatomidae) and Romna sp. (Kirkaldy) (Hemiptera: Miridae) all preyed on heather beetles in cages to a greater degree than more common predators (Table 2).

No microsporidia or other potentially harmful pathogens were detected in any of the samples tested from the crowding experiment.

TABLE 2: The numbers of heather beetle larvae consumed over 2 weeks when caged with individual predators collected from Te Piripiri.

\begin{tabular}{lccc}
\hline Predator & Replicates & Number eaten & Daily consumption rate \\
\hline Control (no predator) & 4 & 0 & 0 \\
Diaea sp. & 8 & 2 & 0.02 \\
Dolomedes minor & 6 & 5 & 0.06 \\
Nabis biformis & 4 & 18 & 0.32 \\
Cermatulus nasalis & 1 & 8 & 0.57 \\
Romna sp. & 1 & 7 & 0.50 \\
\hline
\end{tabular}




\section{DISCUSSION}

These studies show that heather beetles have not recruited any parasitoid natural enemies from the New Zealand fauna since their release and establishment in 1996. This contrasts with levels of parasitism of heather beetle larvae and adults in the United Kingdom, which can approach $100 \%$ and may play an important role in regulating heather beetle populations.

Several predators that could potentially feed on heather beetle were identified from Te Piripiri and other areas where releases had been made within the park. Possible egg predation by carabid larvae, and feeding on heather beetle larvae by the native hemipteran, Cermatulus nasalis (Pentatomidae), were the only predation events witnessed in the field. Moderate numbers of nurseryweb spiders (Dolomedes minor) and crab spiders (Diaea sp.) were sampled from heather dominated vegetation. This finding is consistent with work done by Keesing (1995), who suggested spider numbers increase with the increased architectural complexity that heather introduces to mixed tussock grasslands. However, spiders only occasionally fed on heather beetle larvae and adults in caged trials, and are therefore unlikely to regulate heather beetle populations. The hemipterans, Nabis biformis (Nabidae) and Romna sp. (Miridae), and C. nasalis, were also collected from heather-dominated vegetation. Although these species all fed frequently on heather beetle larvae in laboratory trials, they were only rarely collected from the field even when heather beetle numbers were high. Although more experimental studies of predation could be done, this research suggests that in New Zealand, like the United Kingdom, the heather beetle life stages tested are only sporadically attacked by predators.

With the discovery of high levels of infection by an unidentified and damaging microsporidian in field-collected heather beetles in the United Kingdom, and the uncertainties over the elimination of this disease from heather beetle colonies held in quarantine in New Zealand in the 1990s, there was concern that this pathogen might be causing problems in heather beetle populations in New Zealand. From 1999 to 2001, the heather beetles established at Te Piripiri showed no signs of the disease, such as poor survival or low fecundity, when taken back into laboratory cultures. Further, the results of the crowding experiment suggest no disease was present that could account for the heather beetle population collapse during 2002. Insect diseases usually become obvious if laboratory cultures are subject to crowded and unhygienic conditions (Kluge \& Caldwell 1992). This is very promising evidence that the line rearing and testing were successful in eliminating microsporidia from the heather beetles that were released at Te Piripiri, and that no other disease recruitment has occurred.

Overall, it appears that the heather beetle in New Zealand is relatively enemy-free compared with the United Kingdom. Hence, provided that food is not limiting, and the climate appropriate, heather beetle outbreaks in New Zealand would be expected to be larger and more prolonged than in Europe. So far this has not been the case, with heather beetle numbers collapsing at the one 'outbreak' at Te Piripiri. The collapse in numbers occurred both at the main release site where damage to heather had occurred, and on undamaged, colonised outlier heather patches, so food limitation does not appear to be significant.

It is considered that the poor establishment and success of heather beetle around Tongariro National Park to date is most likely caused by adverse weather conditions. Unseasonably cold conditions in Tongariro National Park in spring 2002, including the lowest minimum temperatures in October for at least 18 years, and unseasonably late snow falls, could have reduced beetle numbers at Te Piripiri. Over the same period, most heather beetle releases at Rotorua, using beetles redistributed from Te Piripiri, established quickly and damaged heather within only 2 years. Rotorua, at $287 \mathrm{~m}$ above sea level, has a mean annual air temperature of $12.8^{\circ} \mathrm{C}$ compared with $9.2^{\circ} \mathrm{C}$ at Waiouru, near Te Piripiri, at $823 \mathrm{~m}$. 
The following four steps to maximise the potential of heather beetle to control heather are suggested.

- Release heather beetle at more sites around Rotorua to provide guaranteed sources of beetles for redistribution.

- Make further releases in and around Tongariro National Park, but concentrate on lower altitudes and warmer sites (to establish core sites for natural and augmented redistribution).

- Continue monitoring predation, parasitism, disease and climate at selected release sites.

- If heather beetle establishment and impact remain poor in and around Tongariro National Park in 2 to 3 years time, then consider re-importing heather beetle from areas in continental Europe with a better climate/latitudinal match to central North Island. Improved methods to detect and eliminate the microsporidian disease from any new heather beetle importations are likely to be needed for this option to be an acceptable risk.

\section{ACKNOWLEDGEMENTS}

We would like to thank Harry Keys and Nick Singers (Department of Conservation), John Mangos (New Zealand Army), Richard Mallinson (Environment Bay of Plenty), Peter Wigley (Biodiscovery), Vaughan Keesing, Ian Andrew and Jens Jorgensen (Massey University), Lindsay Smith, Jo Berry, Marie-Claude Lariviere (Landcare Research) and John Dugdale for their ideas, support and technical assistance. This work was funded by the Foundation for Research, Science and Technology Contract No. C09X0210.

\section{REFERENCES}

Cameron, A.E.; McHardy, J.W.; Bennett, A.H. 1944: The heather beetle (Lochmaea suturalis). British Field Sports Society, Petworth, Sussex. 69 p.

Cornell, H.V.; Hawkins, B.A. 1993: Accumulation of native parasitoid species on introduced herbivores: a comparison of hosts as natives and hosts as invaders. American Naturalist 141: 847-865.

Fowler, S.V.; Peterson, P.; Smith, L; Hill, K. 2000: Heather beetle for biocontrol of heather in and around Tongariro National Park: a progress report. Landcare Research Contract report: LC0001/016. Landcare Research, Lincoln, New Zealand. 36 p.

Golightly, W.H. 1962: Biological control of Lochmaea suturalis (Thomson) (Coleoptera: Chrysomelidae). The Entomologist's Monthly Magazine 98: 196.

Kalmakoff, J.; Longworth. J.F. 1980: Microbial control of insect pests. DSIR Bulletin 228. Wellington, New Zealand.

Keesing, V.F. 1995: Impacts of invasion on community structure: habitat and invertebrate assemblage responses to Calluna vulgaris (L) Hull invasion, Tongariro National Park, New Zealand. PhD thesis, Massey University, Palmerston North, New Zealand. $206 \mathrm{p}$.

Kluge, R.L.; Caldwell, P.M. 1992: Microsporidian diseases and biological control agents: to release or not to release? Biocontrol News Info. 13: 43N-47N.

Smith, L.; Harris, R.J.; Peterson, P.; Syrett, P. 1998: Introduction of Heather beetle Lochmaea suturalis (Thomson) (Coleoptera: Chrysomelidae) into Tongariro National Park as a Biological Control agent for Heather Calluna vulgaris (Ericaceae). Landcare Research Contract Report: LC9798/133. Landcare Research, Lincoln, New Zealand. 7 p.

Syrett, P. 1990: The biological control of heather (Calluna vulgaris) in New Zealand: an environmental impact assessment. Department of Scientific and Industrial Research Plant Protection, Christchurch, New Zealand. 145 p.

Syrett, P.; Smith, L.A.; Bourner, T.C.; Fowler, S.V.; Wilcox, A. 2000: A European pest to control a New Zealand weed: investigating the safety of heather beetle, Lochmaea suturalis (Coleoptera: Chrysomelidae) for biological control of heather, Calluna vulgaris. Bull. Entomol. Res. 90:169-178.

Waloff, N. 1987: Observations on the heather beetle Lochmaea suturalis (Thompson) (Coleoptera: Chrysomelidae) and its parasitoids. J. Natural History 21: 545-556. 